\title{
THE COMPARISON OF FOUR DIFFERENT TREATMENT MODALITIES IN BULKY STAGE IB AND IIA CERVIX CANCERS
}

\author{
Ibrahim Egemen ERTAS, Askin DOGAN, Ulas SOLMAZ, Volkan EMIRDAR, Aykut OZDEMIR, Yusuf YILDIRIM
}

Department of Gynecologic Oncology, Aegean Obstetrics and Gynecology Education and Research Hospital, Izmir

\section{SUMMARY}

Objective: To compare the effectiveness of four different treatment modalities in International Federation of Gynecology and Obstetrics (FIGO) IB2 and IIA2 bulky cervical cancers.

Material and methods: Totally, $n=70$ eligible women with bulky $(\geq 4 \mathrm{~cm})$ FIGO IB2 - IIA2 cervical cancer that diagnosed and treated at our clinic between the years of 1/1994 - 1/2010 were reviewed retrospectively. Data regarding demographic and disease related characteristics were obtained for analysis from patients' files. Different treatment modalities (radical hysterectomy followed by adjuvant chemoradiation (RH + CTRT); primary chemoradiotherapy (CTRT); neoadjuvant chemotherapy followed by radical hysterectomy $(N A C T+R H)$ and neoadjuvant chemoradiotherapy followed by radical hysterectomy $(N A C R T+R H)$ were compared in terms of disease-free survival (DFS) and overall survival (OS) by Kaplan-Meier test. A p value of less than 0.05 was accepted as statistically significant.

Results: Sixty-three patients (90\%) had Stage IB2 and seven (10\%) had stage IIA2 disease. (RH + CRT), (CTRT), $(N A C T+R H)$ and $(N A C R T+R H)$ were performed to 32, 23, 10 and 5 patients, respectively. Mean follow-up period was $78.1 \pm 51.6$ months [range: 10-210]. Thirteen patients (18.6\%) developed recurrence and 10 (14.3\%) died from disease. Mean disease-free (DFS) and overall survival (OS) were $64.6 \pm 46.7$ [4-210] and $68.2 \pm 47.3$ [10-210] months; respectively. No statistically significant difference was found in terms of survival between four treatment methods $(p=0.85$ for DFS and $p=0.9$ for $O S$ ).

Conclusion: The effectiveness of four treatment modalities were similar in terms of survival for patients with bulky FIGO stage IB2 and IIA2 cervical cancers.

Key words: Bulky stage 1b-2a cervix cancer, primary chemoradiotherapy neoadjuvant chemotherapy, neoadjuvant radiotherapy, radical hysterectomy, Journal of Turkish Society of Obstetrics and Gynecology, (J Turk Soc Obstet Gynecol), 2013; Vol: 10, Issue: 1, Pages: 42- 7

\section{EVRE IB VE IIA BULKY SERVIKS KANSERLERINDE DÖRT FARKLI TEDAVI MODALITESININ KARȘILAȘTIRILMASI}

\section{ÖZET}

Amaç: Uluslararası Jinekoloji ve Obstetri Federasyonu (FIGO)'ya göre evre Ib2 evre IIa2 bulky serviks kanserlerinde dört farklı tedavi modalitesinin etkinliğinin karşılaştırılmasıdır.

Gereç ve yöntemler: Kliniğimizde, 1/1994 ve 1/2010 yılları arasında FIGO IB2 - IIA2 serviks kanseri tanısı alan ve tedavi edilen toplam 70 uygun hasta retrospektif olarak incelendi. Demografik veriler ve hastalikla ilişkili karakteristikler analiz iç in hasta dosyalarından elde edildi. Farkl tedavi modaliteleri, radikal histerektomi ve adjuvan kemoradyoterapi $(R H+K T R T)$, primer kemoradyoterapi $(K T R T)$, neoadjuvan kemoterapi takiben radikal histerektomi $(N A K T+R H)$, neoadjuvan kemoradyoerapi takiben radikal histerektomi (NAKRT $+R H)$ hastalıksız sağkalım (HS) ve genel sağkalım

Address for Correspondence: İbrahim Egemen Ertaş. Ege Doğumevi ve Kadın Hastalıkları Eğitim ve Araştırma Hastanesi, Jinekolojik Onkoloji Kliniği, İzmir Phone: + 90 (505) 7404206 e-mail: drertas@gmail.com

Received: 10 May 2012, revised: 18 October 2012, accepted: 14 November 2012, online publication: 15 November 2012 
(GS) açısından Kaplan-Meier testi kullanılarak karşılaştırıldı. $P<0.05$ istatistiksel olarak anlamlı kabul edildi. Sonuçlar: Altmış-üç (\%90) hasta evre Ib2 ve 7 hasta evre IIa2 idi. $(R H+K R T)$, primer (KTRT), (NAKT + RH) ve $(N A K R T+R H)$ sırası ile 32, 23, 10 ve 5 hastaya uyguland. Ortalama takip süresi 78.1 5 51.6 ay [dağılım: 10-210] olarak tespit edildi. Onüç (\%18.6) hastada rekürrens gelişti ve 10 (\%14.3) vaka hastalıkdan kaybedildi. Ortalama HS ve GS sirasıyla $64.6 \pm 46.7$ [4-210] ve 68.2 47.3 [10-210] idi. Yaşam süreleri aç ısından dört tedavi yöntemi arasında istatistiksel anlamlı fark bulunmadı (HS iç in $p=0.85$ ve GS iç in $p=0.9$ ).

Tartışma: Bulky FIGO evre IB2 ve IIA2 serviks kanserli hastalarda dört farkl tedavi modalitesinin etkinliği să̆kalım açısından benzerdir.

Anahtar kelimeler: Bulky evre 1b-2a serviks kanseri, neoadjuvan kemoterapi, neoadjuvan radyoterapi, primer radyokemoterapi, radikal histerektomi Türk Jinekoloji ve Obstetrik Derneği Dergisi, (J Turk Soc Obstet Gynecol), 2013; Cilt: 10, Sayl: 1, Sayfa: 42- 7

\section{INTRODUCTION}

Cervix cancer is the second highest mortality rate of cancer after breast among women all over the world and the course of patients with advanced stage disease is worse ${ }^{(1-3)}$. Radical hysterectomy with systematic pelvic and paraaortic lymphadenectomy is considered to be the standard therapy for patients with early stage cervical cancer. But the rate of recurrence is as high as 30 percent in only surgery performed patients ${ }^{(2-3)}$. The optimal management of locally advanced cervical tumors measuring $\geq 4 \mathrm{~cm}$ diameter is controversial in the literature. In locally advanced cervix cancers, there are four different treatment modalities are put into practice including radical hysterectomy followed by adjuvant chemoradiation ( $\mathrm{RH}+\mathrm{CTRT})$, primary chemoradiotherapy (CTRT), neoadjuvant chemotherapy followed by radical hysterectomy (NACT $+\mathrm{RH})$, and neoadjuvant chemoradiation therapy followed by radical hysterectomy (NART + RH) ${ }^{(1-5)}$.

In a randomised study of radical surgery versus radiotherapy in stage IB-IIA cervical cancers, the cure rate of each options yield similar 5 year survival rates ranging between $70-95 \%(4)$. Adjuvant radiotherapy treatment is carried out when postoperative pathological examinations reveal risk factors for recurrence, including deep stromal invasion (DSI), lymphovascular space invasion (LVSI), parametrial invasion (PI), lymph node metastasis (LNM), and bulky tumor(3-5). Regardless of treatment, patients with $\geq 4 \mathrm{~cm}$ bulky tumors had more recurrence and worse survival rates than patients with stage IB $1^{(5-8)}$. The 5 year survival rate for patients with tumor size greater than $3 \mathrm{~cm}$ was only $30-60 \%$ compared to 5 year survival of $70-90 \%$ in patients with tumor size less than or equal to $3 \mathrm{~cm}$ $(7,9,10)$. There is no clear consensus in terms of treatment modalities for stage IB2 and IIA2 cervical cancers between centers in the worldwide. In the light of these attainments, the goal of this retrospective study was to compare the effectiveness of four different treatment methods in the management of stage IB2 and IIA 2 cervical cancers.

\section{MATERIAL AND METHODS}

In this retrospective study, totally 70 eligible women with complete information and bulky ( $\geq 4 \mathrm{~cm}$ ) FIGO stage IB2 and IIA2 cervical cancer that diagnosed and treated at Department of Gynecologic Oncology, Aegean Obstetrics and Gynecology Education and Research Hospital, Izmir, Turkey between the years of 1/1994 - 1/2010 were analyzed. Data regarding demographic and disease-related characteristics were obtained from patient's files. Four different treatment modalities; adjuvant chemoradiation after radical hysterectomy $(\mathrm{RH}+\mathrm{CTRT}) \mathrm{n}=32$; primary concomitant chemoradiation (CTRT) $n=23$; neoadjuvant chemotherapy followed by radical hysterectomy (NACT $+\mathrm{RH}) \mathrm{n}=10$; neoadjuvant chemoradiation followed by radical hysterectomy (NACRT $+\mathrm{RH}) \mathrm{n}=5$ were compared in terms of disease-free survival (DFS) and overall survival (OS). Institutional Review Board approval was obtained from our center.

The patients who had histologically proven cervical cancer, stage IB2-IIA2 bulky ( $\geq 4 \mathrm{~cm}$ in diameter) according to International Federation of Gynecology and Obstetrics new (FIGO) 2009 criteria, adequate hematologic, renal, and liver function tests and no evidence of secondary neoplasm were included to the study. Stage of disease and tumor dimension were evaluated with rectovaginal examination, colposcopy, abdominopelvic 
ultrasound, combination of magnetic resonance (MRI) and computerized tomography (CT).

Primary adjuvant chemotherapy (cisplatin $40 \mathrm{mg} / \mathrm{m} 2$ weekly) were administered 3-5 times and radiotherapy was performed as brachytherapy and externally to all patients. As neoadjuvant chemotherapy; three cycles paclitaxel $60 \mathrm{mg} / \mathrm{m} 2$ plus cisplatin $40 \mathrm{mg} / \mathrm{m} 2$ every ten days and as neoadjuvant chemoradiotherapy external-beam radiotherapy to 45 Gy plus weekly cisplatin $50 \mathrm{mg} / \mathrm{m} 2$ were administered. Surgery was performed 3-4 weeks after completion of the preoperative treatments. After surgery adjuvant chemotherapy + brachytherapy + pelvic radiotherapy was administered to all patients. Adjuvan extended field radiotherapy was performed to 9 patients. Statistical analysis was performed with SPSS 16.0 statistical package program (SPSS, Inc., IL, Chicago, USA) by using Kaplan-Meier test. A p value of less than 0.05 was accepted as statistically significant.

\section{RESULTS}

Sixty-three patients $(90 \%)$ had bulky FIGO Stage IB2 and $7(10 \%)$ had stage IIA2 cervical cancer. The clinical tumor size ranged from 4.1 to $10 \mathrm{~cm}$, with a mean tumor diameter of $5 \mathrm{~cm}$. Patients' clinical and surgicopathologic characteristics are presented in Table 1. Histologic cell types include $\mathrm{n}=60(85.7 \%)$ squamous cell carcinomas, $\mathrm{n}=6(8.5 \%)$ adenocarcinoma, and $\mathrm{n}=4(5.8 \%)$ adenosquamous carcinoma. Pathologic research showed parametrial involvement in $2(2.85 \%)$ patients. Seven $(10 \%)$ patients had LVSI, and only one patient had positive surgical margins. Nine $(12.8 \%)$ patients had pelvic and/or paraaortic nodal metastases.

$\mathrm{RH}+\mathrm{CTRT}$, primary CTRT, NACT $+\mathrm{RH}$ and NACRT $+\mathrm{RH}$ were performed to $\mathrm{n}=32, \mathrm{n}=23, \mathrm{n}=10$ and $\mathrm{n}=$ 5 patients, respectively. Mean follow-up period was 78.1 \pm 51.6 months [range: $10-210$ months]. Thirteen patients (18.6\%) developed recurrence and 10 (14.3\%) died from disease. Mean disease free (DFS) and overall survival (OS) were $64.6 \pm 46.7$ [4-210] and 68.2 \pm 47.3 [10-210] months; respectively. In NACRT + RH group, one patient developed vesicovaginal fistula, and in RH + CTRT one patient developed long-term hydronephrosis that needed urethral stenting. Five year disease free and overall survival rates for $(\mathrm{RH}+\mathrm{CTRT})$; (CTRT); (NACT + RH); (NACRT $+\mathrm{RH})$ groups are found as $88 \pm 6 \% ; 80 \pm 8 \% ; 100 \%$; 80 $\pm 8 \%$ and $93 \pm 4 \% ; 86 \pm 4 \% ; 100 \% ; 84 \pm 4 \%$, respectively. No statistically significant difference was found in terms of survival between four treatment methods ( $p=0.85$ for DFS and $p=0.9$ for OS), (Table II, Fig.1 and 2).

Table I: Clinical and surgicopathologic characteristics of the study patients

\begin{tabular}{|c|c|c|c|c|}
\hline & $\begin{array}{c}\text { RH + CTRT } \\
(n=32)\end{array}$ & $\begin{array}{c}\text { CTRT } \\
(n=23)\end{array}$ & $\begin{array}{c}\text { NACT + RH } \\
(\mathbf{n}=\mathbf{1 0})\end{array}$ & $\begin{array}{c}\text { NACRT + RH } \\
(n=5)\end{array}$ \\
\hline Age* $^{*}$ & $50[34-65]$ & $48[36-70]$ & $48[42-59]$ & $48[42-50]$ \\
\hline \multicolumn{5}{|l|}{ Tumor Type** } \\
\hline Squamous cell cancer & $26(81.25)$ & $19(82.6)$ & $10(100)$ & $5(100)$ \\
\hline Adenocancer & $4(12.5)$ & $2(8.7)$ & - & - \\
\hline Adenosquamous cancer & $2(6.25)$ & $2(8.7)$ & - & - \\
\hline \multicolumn{5}{|l|}{ Tumor Size $* * *$} \\
\hline $4 \mathrm{~cm}$ & 12 & 11 & 6 & 2 \\
\hline $5-6 \mathrm{~cm}$ & 17 & 8 & 4 & 2 \\
\hline $7-8 \mathrm{~cm}$ & 2 & 1 & - & - \\
\hline $9-10 \mathrm{~cm}$ & 1 & 2 & - & 1 \\
\hline$>10 \mathrm{~cm}$ & - & 1 & - & - \\
\hline \multicolumn{5}{|l|}{ FIGO Stage $* * *$} \\
\hline IB2 & 31 & 17 & 10 & 5 \\
\hline IIA2 & 1 & 6 & - & - \\
\hline LVSİ*** & 5 & - & 2 & - \\
\hline Parametrial involvement $* * *$ & 2 & - & - & - \\
\hline Positive surgical margin*** & 1 & - & - & - \\
\hline Pelvic and/or paraaortic nodal metastases*** & ** & - & - & 1 \\
\hline
\end{tabular}

Values are expressed as $*$ median with range, **: $n(\%), * * *: n$

$\boldsymbol{R H}+\boldsymbol{C T R T}$ : radical hysterectomy followed by adjuvant chemoradiation; CTRT: primary chemoradiotherapy;

$\mathbf{N A C T}+\mathbf{R H}$ : neoadjuvant chemotherapy followed by radical hysterectomy; $\mathbf{N A C R T}+\boldsymbol{R H}:$ neoadjuvant chemoradiotherapy followed by radical hysterectomy

LVSI: Lymphovascular space involvement 
Table II: Disease free and overall survival rates with respect to treatment modalities.

\begin{tabular}{lcc}
\hline & $\begin{array}{c}\text { Tahmini } \\
\text { 5 yıllık HS }\end{array}$ & $\begin{array}{c}\text { Tahmini } \\
\text { 5 yıllı GS }\end{array}$ \\
\hline RH + KTRT & $88 \pm 6$ & $93 \pm 4$ \\
KTRT & $80 \pm 8$ & $86 \pm 4$ \\
NAKT + RH & 100 & 100 \\
NAKRT + RH & $80 \pm 8$ & $84 \pm 4$ \\
Log Rank (Mantel Cox) $\mathbf{p}$ & 0.85 & 0.9 \\
\hline
\end{tabular}

Values are expressed as rate (\%) \pm standart deviation, DFS: Disease free survival, OS: Overall survival

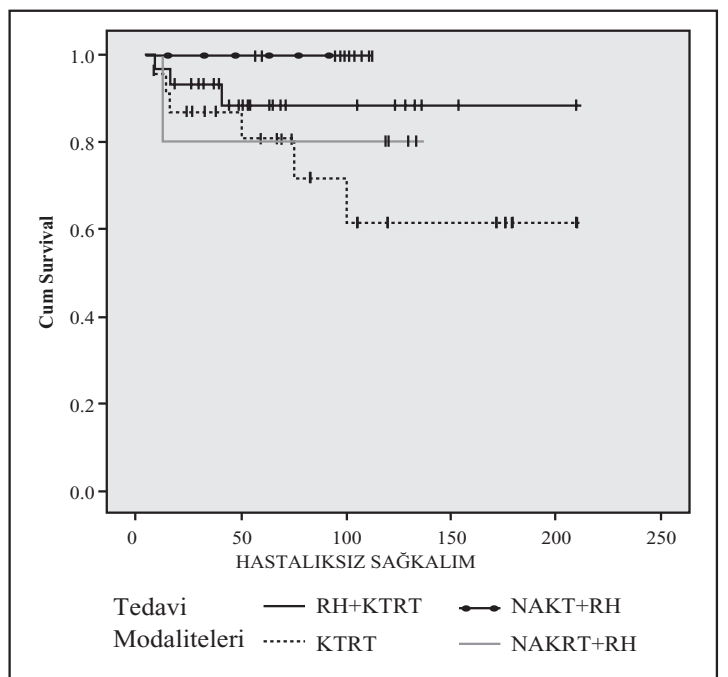

Figure 1: Disease free survival curve regarding to four different treatment modalities.

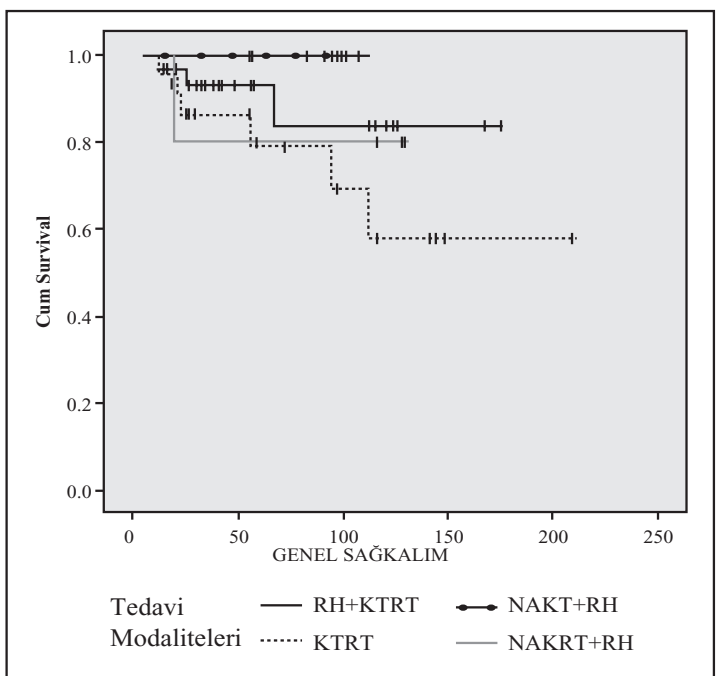

Figure 2: Overall survival curve regarding to four different treatment modalities.

\section{DISCUSSION}

The ideal management of bulky cervical tumors shows differences between centers in the worldwide. Patient factors like age, fertility desire, medical status, tumor charecteristics (tumor volume, depth of invasion, lymphovascular space invasion, lymph node metastases status, histopathologic type) and the experience of clinicians are the factors concerning treatment modality. Both radical surgery and radiotherapy have proven to be equally effective, but differ in terms of morbidity and complications. Radical surgery has some advantages as ovarian function sparing and avoid the effects of early menopause in young women when compared with radiotherapy. Patients who have comorbidities and contraindications for surgery also benefit from radiotherapy. There are some conflicting published datas regarding the treatment of bulky stage IB-IIA cervical cancer $(3,8,9,11)$. While some centers are performing primary surgery for stage IB2 disease followed by tailored postoperative radiation with or without chemotherapy, the others are in favor of primary chemo-radiation therapy. Today there is no agreement for the treatment of bulky cervical cancers and there are few studies to evaulate the efficacy of different type of treatments in the literature.

The 5-year survival rate of radical hysterectomy and radiation therapy was $78-92 \%$ versus $65-90 \%(11)$. Because of unfavorable survival rates with single treatment method like radical surgery or radiation therapy alone in patients with bulky stage IB, other treatment modalities have been required to achieve and improve the local control and enhance survival. Rushdan et al. ${ }^{(12)}$ reported that treatment with surgery and radiotherapy significantly decreased the recurrence rate and improved overall survival in patients with cervical carcinoma compared to surgery alone. CTRT is one of the most used treatment modality in bulky cervical cancers. In this context chemotherapeutic agents (especially cisplatin) are effective in eradicating the subclinical metastasis and act as a radiosensitizer. However, 5-fluorouracil (5-FU), hydroxyurea, ifosfamide, mitomycin- $\mathrm{C}$, and bleomycin have also been used for this purpose ${ }^{(13,14)}$. Moris et al. showed that the CTRT is superior to the radiation alone in the treatment of locally advanced cervical cancer with 5year overall survival rate $58 \%$ and $73 \%$ respectively (15). The original cochrane review which include 4580 
patients strongly suggested that chemoradiation improves overall survival, progression free survival and also demonstrated significant benefit for local and distant recurrence ${ }^{(16)}$.

Positive lymph node status, positive/close surgical margins, and parametrial invasion are the risk factors for recurrence in cervical cancers. The patients with these risk factors benefited from adjuvant chemo/ radiation after radical hysterectomy $(2,3,16,17)$. Adding concurrent chemoradiotherapy to patients who have tumor size greater than $2 \mathrm{~cm}$ has been found more advantageous and has shown 19\% improvement in 5 year survival(17).

For improving resectability rate, neoadjuvan chemotherapy or neoadjuvant chemoradiotherapy can be used prior to surgery. Administrating chemotherapy before radical surgery might shrink the tumour. This could make surgery easier and it may also help to remove any tiny tumours that cannot be easily seen $(18,19)$. There was no randomized phase III trial between neoadjuvan chemotherapy and concurent chemoradiation in bulky stage IB cervical cancers. Modaress et al. noted that neoadjuvant chemotherapy and chemoradiation had similar effects in survival prognostic factors ${ }^{(20)}$. Panici et al. showed statistically significant survival rates between neoadjuvan chemotherapy followed by radical hysterectomy + pelvic lymphadenectomy group and radiation therapy alone group in locally advanced cervical cancer (5 year OS and DFS rate of 59\% and 55\% in neoadjuvan chemotherapy arm, $44 \%$ and $44 \%$ in radiotherapy arm) (21). Moreover; the first randomized trial using neoadjuvant chemotherapy in stage IB squamous carcinoma showed significantly improved survival rates $^{(22)}$. In a retrospective study performed in Turkey, Turan et al. evaluate and compare the efficacy of three treatment modalities NACT $+\mathrm{RH}, \mathrm{RH}+\mathrm{CTRT}$ and primary radiotherapy in 74 patients with stage IB2 cervical cancer and concluded that none of the treatment modalities had any superior effect on survival(23). In another study by Özgül et al. including 36 cases evaluated the factors determining response to neoadjuvant chemotherapy in stage IB2 cervix cancer and reported that neoadjuvant chemotherapy is more effective only in elderly patients but such factors like tumor size and pathology, chemotherapy protocol and number of cycles are not effective ${ }^{(24)}$. In our series, 5 year OS was $93 \pm 4 \%$ for RH + CTRT, $100 \%$ for
$\mathrm{NACT}+\mathrm{RH}$ and, $86 \pm 4 \%$ for primary CTRT respectively. In the light of these premices, it can be concluded that our results are in concordance with previous published large sampled studies.

Although the weak point of this study is the small number of patients especially in NACRT + RH group, our results represent important clues in terms of treatment decision for bulky stage IB2 and IIA2 cervical cancers. According to the best of authors' knowledge, the different side of this article is the first performed study in Turkey that searching the efficacy of four treatment modalities in the management of bulky cervix cancers.

\section{CONCLUSION}

We demonstrated that the effectiveness of four treatment modalities were similar in terms of survival for patients with bulky FIGO stage IB2 and IIA2 cervical cancers. Moreover; the treatment decision and type should be individualized by evaluating multiple factors including the stage of disease, age, medical condition of the patient, tumor-related factors for yielding the best cure with minimum complications. Further large sample sized studies are needed to evaluate the efficacy of treatment modalities in patients with bulky stage IB2 and IIA2 cervical cancer.

\section{REFERENCES}

1. Monk BJ, Tewari KS, Koh WJ. Multimodality therapy for locally advanced cervical carcinoma: state of the art and future directions. J Clin Oncol. 2007; 25(10): 2952- 65.

2. Dreyer G. Operative management of cervical cancer. Best Pract Res Clin Obstet Gynaecol. 2005; 19(4): 563- 76.

3. Kesic V. Management of cervical cancer. Eur J Surg Oncol. 2006; 32(8): 832- 7 .

4. Landoni F, Maneo A, Colombo A, Placa A, Milani R, Perego $P$, et al. Randomised study of radical surgery versus radiotherapy for stage Ib-IIa cervical cancer. Lancet. 1997; 350(9077): 535- 40

5. Hosaka M, Watari H, Takeda M, Moriwaki M, Hara Y, Todo $\mathrm{Y}$, et al. Treatment of cervical cancer with adjuvant chemotherapy versus adjuvant radiotherapy after radical hysterectomy and systematic lymphadenectomy. J. Obstet Gynaecol. Res. 2008; 34(4): 552- 6. 
6. Delgado G, Bundy BN, Fowler Jr WC, Stehman FB, Sevin $\mathrm{B}$, Creasman WT, et al. A prospective surgical pathological study of stage I squamous carcinoma of the cervix: a Gynecologic Oncology Group Study. Gynecol Oncol. 1989; 35(3): 31420 .

7. Perez CA, Grigsby PW, Nene SM, Camel HM, Galakatos A, Kao MS, et al. Effect of tumor size on the prognosis of carcinoma of the uterine cervix treated with irradiation alone. Cancer. 1992; 69(11): 2796- 806.

8. Homesley HD, Raben M, Blake DD, Ferree CR, Bullock MS, Linton EB, et al. Relationship of lesion size to survival in patients with stage IB squamous cell carcinoma of the cervix uteri treated by radiation therapy. Surg Gynecol Obstet. 1980; 150(4): 529- 31.

9. Thoms WW Jr, Eifel PJ, Smith TL, Morris M, Delclos L, Wharton JT, et al. Bulky endocervical carcinoma: a 23-year experience. Int J Radiat Oncol Biol Phys. 1992; 23(3): 4919.

10. Gauthier P, Gore I, Shingleton HM, Soong SJ, Orr JW Jr, Hatch KD. Identification of histopathologic risk groups in stage IB squamous carcinoma of the cervix. Obstet Gynecol. 1985; 66(4): 569- 74.

11. Petsuksiri J, Chansilpa Y, Therasakvichya S, Suntornpong N, Thephamongkhol K, Dankulchai P, et al. Treatment options in bulky stage IB cervical carcinoma. Int J Gynecol Cancer. 2008; 18(6): 1153- 62 .

12. Rushdan MN, Tay EH, Khoo-Tan HS, Lee KM, Low JH, Ho $\mathrm{TH}$, et al. Tailoring the field and indication of adjuvant pelvic radiation for patients with FIGO stage Ib lymph nodes-negative cervical carcinoma following radical surgery based on the GOG scorea pilot study. Ann Acad Med Singapore. 2004; 33(4): 467- 72 .

13. Fu KK. Biological basis for the interaction of chemotherapeutic agents and radiation therapy. Cancer. 1985; 55(9): 2123- 30.

14. Stehman FB, Bundy BN, Kucera PR, Deppe G, Reddy S, O'Connor DM. Hydroxyurea, 5- fluorouracil infusion, and cisplatin adjunct to radiation therapy in cervical carcinoma: A phase I-II trial of the Gynecologic Oncology Group. Gynecol Oncol. 1997; 66(2): 262- 7.

15. Morris M, Eifel PJ, Lu J, Grigsby PW, Levenback C, Stevens RE, et al. Pelvic radiation with concurrent chemotherapy compared with pelvic and paraaortic radiation for high- riskcervical cancer. N Engl J Med. 1999; 340(15): 1137- 43.

16. Green J, Kirwan J, Tierney J, Symonds P, Fresco L, Williams $\mathrm{C}$, et al. Concomitant chemotherapy and radiation therapy for cancer of the uterine cervix. Cochrane Database Syst Rev. 2001; 4: CD002225.

17. Green J, Kirwan J, Tierney J, Vale C, Symonds P, Fresco L, et al. Concomitant chemotherapy and radiation therapy for cancer of the uterine cervix. Cochrane Database Syst Rev. 2005; 3: CD002225.

18. Robova H, Halaska M, Pluta M, Skapa P, Strnad P, Lisy J, Rob L. The role of neoadjuvant chemotherapy and surgery in cervical cancer. Int J Gynecol Cancer. 2010; 20(11 Supp12): 42- 6 .

19. Morice P, Uzan C, Zafrani Y, Delpech Y, Gouy S, HaieMeder C. The role of surgery after chemoradiation therapy and brachytherapy for stage IB2/II cervical cancer. Gynecol Oncol. 2007; 107(1 Suppl 1): 122- 4.

20. Modarress M, Maghami FQ, Golnavaz M Behtash N, Mousavi A, Khalili GR. Comparative study of chemoradiation and neoadjuvant chemotherapy effects before radical hysterectomy in stage IB-IIB bulky cervical cancer and with tumor diameter greater than $4 \mathrm{~cm}$. Int J Gynecol Cancer. 2005; 15(3): 4838.

21. Benedetti-Panici P, Greggi S, Colombo A, Amoroso M, Smaniotto D, Giannarelli D, et al. Neoadjuvant chemotherapy and radical surgery versus exclusive radiotherapy in locally advanced squamous cell cervical cancer: results from Italian multicenter randomized study. J Clin Oncol. 2002; 20(1): 179- 88.

22. Sardi JE, Giaroli A, Sananes C, Ferreira M, Soderini A, Bermudez A, et al. Long-term follow-up of the first randomized trial using neoadjuvant chemotherapy in stage Ib squamous carcinoma of the cervix: the final results. Gynecol Oncol. 1997; 67(1): 61- 9 .

23. Turan T, Yildirim BA, Tolunay G, Boran N, Yıldız F, Köse MF. Experience in stage IB2 cervical cancer and review of treatment. J Turkish-German Gynecol Assoc 2010; 11: 2737.

24. Ozgul N, Turan T, Kucukelcı I, Tulunay G, Born T, Ozer S, et al. The factors which is predict the response to neoadjuvant chemotherapy in stage IB2 cervical cancer. J Turkish-German Gynecol Assoc 2008; 9(3): 152- 7. 